\section{Letrônica}

\title{
A contrastive overlook at Asian literature in the Americas: two examples
}

Um olhar contrastivo sobre a literatura asiática nas Américas: dois exemplos

José I. Suárez

University of Northern Colorado. Greeley, Colorado, USA

Professor of Hispanic Studies at the University of Norhen Colorado. He has published over hy published five books. Among his book publications and co-publications on literature feature"The Carnival Stage: Vicentine Comedy within the SerioComic Mode", "Gill Vicente's The Play of Rubena", and "Mario de Andrade: The Creative Works". Emat:
ABSTRACT: This paper will critically explore and compare East Asian perspectives and adaptation modes in the Americas as well as self-perception within the realm of "the Other" through two novels: Yawara! A Travessia Nihondin-Brasil (Yawara! The Nihondin-Brazil Journey 2006) by Júlio Miyazawa, a Nipo-Brazilian (Nisei), and Yellow on the Outside, Shame on the Inside: Asian Culture Revealed by the Sino-American Anson Chi (Web published).

Keywords: Nisei; emigration; Other; Asianness.

RESUMO: 0 presente artigo explora e compara criticamente as perspectivas do Leste Asiático e seus modos de adaptação nas Américas, bem como a autopercepção no âmbito do "Outro" em dois romances: Yawara! A travessia Nihondin-Brasil (2006), de Júlio Miyazawa, um nipo-brasileiro (nissei), e Yellow on the Outside, Shame on the Inside: Asian Culture Revealed (Amarelo por fora, vergonha por dentro: cultura asiática revelada), do sino-americano Anson Chi (publicado na Web).

Palavras-chave: Nissei; Emigração; Outro; Cultura asiática. 
$1 \mathrm{cor}$ hroughout the hemisphere, Asian-American literature shares

commonalities given that it draws most of its inspiration from the shared experiences of immigrants and their descendants in their adoptive countries. However, this is not to say that the perspectives of these individuals are the same. The purpose of this paper is to examine two works, one by a Japanese Brazilian, the other by a Chinese American, to explore and compare their self-perception within the realm of "the Other."

The end of feudalism in Japan in 1871, with the 1868 advent of the Meiji Restoration, created great hardship among its peasant class and prompted emigration. These migrants planned to save money and to return to Japan, but working conditions in their adoptive countries made this expectation virtually unrealizable. With the end of the slave trade in 1888, Brazil began to encourage Japanese immigration to replenish its work force. As a result, Japanese immigrants and their families were able to settle in this country when no longer welcomed in the United States and Canada, countries to where they initially emigrated, and that later opposed Japan's expansionist policies (BODNAR, 1985, p. 55-56).

However, given extant racial policies, how were Brazilians to reconcile their labors needs with non-white field hands? Even though in 1910 Brazilian legislators passed a bill prohibiting federal subsidies for Asian immigrants, Japanese farm workers were excluded from the "Asian" category and included in the "highly desirable" European category (HIRABAYASHI, 2002, p. 38). Amazingly, as Jeffrey Lesser reveals:

Brazilian [race] notions were reinforced by Japanese diplomats who eagerly promoted the notion that their subjects were "white." Soon a "model minority" discourse (to use a contemporary concept) emerged that suggested that Japanese immigrants would lead Brazil to military and industrial power by recreating Japan's ostensible homogeneous society. As deputy Nestor Ascoli noted regarding Russia's defeat in its 1904-05 war with Japan, "the Japanese is now a better element of progress than the Russian and other European peoples." By harping on the idea that "intellectually the Japanese is frighteningly superior," Ascoli suggested that immigrants would help Brazil match the production levels of Japanese industry. (HIRABAYASHI, 2002, p. 38-39).

Such a policy understandably attracted many Japanese to Brazilmostly to the southern states of São Paulo, as mentioned, and Paranáto an extent that Brazil took in the largest number of Japanese émigrés anywhere, except for Manchuria, during the thirty years after their initial arrival in 1908. Of the 35,000 who arrived between 1908 and 1925, most transitioned from field laborers to small farm owners within two to five years. Immigration to Brazil continued to grow substantially. In 1928, Brazil stopped subsidizing immigration, yet this measure did not reduce the large number of arrivals. The explanation is that, in 1924, the Japanese government had begun to subsidize its emigrants to found colonies in Brazil, thereby encouraging emigration to that country. Prompted by the Great Depression and a threatening rise of Japanese nationalism, the Brazilian government passed the 1934 Immigration Act putting an end to the Japanese influx (MASTERSON, 2004, 72-82).

During the remainder of the thirties and throughout World War II, the situation became difficult for those Japanese already settled in Brazil. Getúlio Vargas's dictatorship (1930-1954) returned to the "whiteness through assimilation" policy of the late nineteenth-century by enacting stringent measures to ensure its outcome. On July 10, 1943 approximately ten thousand alleged Axis sympathizers, ninety percent of whom were Japanese, were rounded up with no warning, and forced to leave the city of Santos in the State of São Paulo. They were forbidden from taking their belongings. By war's end, Japanese Brazilians were viewed as fanatics and terrorists by most non-Japanese Brazilians. All were associated with acts committed by the Shindo-Renmei organization, a secret terrorist group established in 
1944 whose mission was an attempt to preserve "Japaneseness" along with emperor worship, thereby creating a country for those who felt that they had none (SUZUKI JR., 2008).

With the end of the Second War, the waning of the Estado Novo, and the dismantling of Shindo-Renmei, Japanese Brazilians entered an era of prosperity despite prevailing ethnic prejudices; immigration continued (circa 200,000 Japanese arrived in the 1950s). Their acknowledgement of Japan's defeat--a fact many denied at the end of the war--the realization that they would not return to live in Japan and their acceptance of Brazil as yokoku (adopted country) facilitated their upward mobility and integration within Brazilian society.

Júlio Miyazawa's Yawara! A Travessia Nihondin-Brasil is a highly polished fictional work (it earned the 2009 Nikkei Literary Award). Divided into three parts, it details the post-WWII trials and tribulations of three Japanese immigrant families in the state of São Paulo. The first part, "Pátria Amada" ("Beloved Homeland") describes a harsh and isolated life in the community they founded in $1936^{1}$. Among the hardships endured, the worst was the prejudice of non-Asian Brazilians directed against them, to the point of physical attacks, particularly during the 1940s. This first part ends with the suicide of Kenhiti (he served prison time for an altercation he had with a non-Asian Brazilian) and that of his wife Akemi. Both jumped off a cliff, deliriously believing that they were back in Japan and shouting, "Fuji-San! Pátria Amada!"

The second part, skipping to the 1970s, takes its title, "Mariano Goro", from the name of the offspring of Kenhiti and Akemi, who was adopted by a Japanese family after their suicide and who is this section's protagonist. Whereas in the first part, the migrants' acceptance of their "Otherness"

\footnotetext{
${ }^{1}$ All translations are mine.
}

is one of resignation because of their "Asianness," which stands patently counter to the "Brazilianness" of those "belonging" and who exert their sense of "superiority" whenever the two groups clash, with Mariano, a Nisei, a generation has arisen that is "neither/nor," that is, it is neither entirely Brazilian nor entirely Japanese. This conundrum has psychological implications, as Mariano verbalizes:

Am I Brazilian or Japanese? It may seem like a foolish question because my identification papers prove that I was born here and that I am Brazilian However, my physical characteristics expose my Japanese origins. It's in my face! Many Niseis born in postwar Brazil faced that false dilemma. Their individual experiences, coupled with their socioeconomic status, produced, to a lesser or greater extent, personality disorders conditioned by that false dilemma (MIYAZAWA, 2006, p. 124-125).

In his own case, he was diagnosed with dissociative identity disorder after having to be hospitalized. In fact, Mariano disassociates himself from his political militancy by creating a double, the insurgent Caro Mano (the "Jap"), whom he feels that he is protecting by not revealing his identity and culpability when he, Mariano, is pursued and apprehended for his own transgressions against the government. He later acknowledges this duality: "It was then that I think I became two people: I was Mariano, a Japaneseborn Brazilian and therefore a Brazilian, but I was also the Jap, sought after by the police for political reasons..." (MIYAZAWA, 2006, p. 164).

What exacerbates the Nisei identity condition is that in Brazil, like in the United States, racial discourse centers on the "black and white" binary. Those who are not from African or European descent fall outside the "them vs. us" dichotomy; they are either excluded in discussions of the nation's racial underpinnings, or are appropriated when it suits the empowered group, as evidenced in their "non-Asian" category in the 1910 legislation (UBA, 2003, p. 77). Mariano thus is left in an identity limbo that keeps him as 
a "neither/nor" and sustains his split personality: "And I? What nationality am I to claim? As many of us did, for a long time I tried to look Brazilian, despite my Japanese face" (MIYAZAWA, 2006, p.127). Sadly, at an early age he comes to see miscegenation as the eventual solution to his people's plight: "Bento was a different type of Japanese. He was a mestiço (mix-blood) who... was unaware of Japanese like us. Being a little over ten years old and having suffered discrimination for being Japanese, I was a bit envious of Bento. I wished to be like him, of being mestiço as well!" (MIYAZAWA, 2006, p.138). Unlike the U.S., Brazil considers many of its mix-blood individuals "white."

"A Travessia" ("The Journey") is the title of the final part. It is a fitting title because Miyazawa masterfully succeeds in encapsulating the Japanese experience in Brazil through these pages. For the protagonist Koiti, a founding member of the Atibaia community and now the fictional collective voice of Japanese migrants, it is a journey from Japan to Brazil, from rural colonies to the city of São Paulo, from immigrant to citizen, from youth to old age but, primarily, it is a metaphor for Issei transition from identity crisis to self confirmation and realization. The "journey" is, therefore, one of acculturation. While in attendance at a Japanese film, Koiti breaks down emotionally and, crying, shouts out "Kenhiti!," the name of his fellow immigrant who committed suicide ten years earlier. The overall societal oppression that Koiti felt forced him to immediately bury the memory at the time of his friend's tragic end. He, as is the case with many minority members, subconsciously repressed a traumatizing event that could impede his objective: becoming financially successful to prove the majority group wrong regarding its views of Japanese inferiority. Koiti's price, a type of mental John Henryism, is psychological breakdown and family disintegration-he separated from his wife Minako soon after their arrival to the city.
While sobbing at the movie theater, Koiti is approached by Mitiko, a Nisei also known as Michan, who tries to sooth him. He momentarily goes outside without her, recomposes himself, thinks of his life since his arrival in Brazil, and returns to view the movie. Afterward, he introduces himself to her. The tumultuous relationship that ensues is framed within cinematographic parameters. Mitiko and particularly Koiti are portrayed as and behave like movie characters. For example, while on an outing, Miyazawa emphasizes the film setting of his narration: "It looked like a movie scene where the actors were not acting, but just calmly walking" (MIYAZAWA, 2006, p. 199). Later, trying to patch up their affair on a rainy day, Koiti breaks out in the song and dance of the American 1952 film Singing in the Rain "trying to imitate the singer-and-dancer actor Gene Kelley in that iconic scene" (MIYAZAWA, 2006, p. 208). The scene is included as a literary device. On the one hand, it is paradoxical that two Japanese Brazilians who, according to the novel, mainly watch Japanese films, should act out a scene from an American movie. On the other hand, the author must have felt compelled to use a scene from a film that is known to most readers (Japanese-film viewing is limited outside Japan). Also, his choice purposely serves his portrayal of Koiti, a man torn between his "Japaneseness" or "Easternness" (who he was originally) and his "Brazilianness" or "Westernness" (who he has partially become). The scene is neither plausible nor implausible. It is this "neither/ nor" that conveys the protagonist's identity ambivalence.

Koiti's journey starts at the movie theater with his breakdown and his ensuing relationship with Mitiko. She, although not born in Japan, has a strong sense of identity owing to her upbringing and her father's constant reminder: "You Michan! You Okinawa! You, Micham from Okinawa. Don't you ever forget it!" (MIYAZAWA, 2006, p. 194). Through her and her family, Koiti slowly undergoes the process of understanding his and his people's uniqueness in Brazil. He tells Mitiko the story of Kootaro, a boy in his 
community who, on reaching adulthood, went to research and to live for five years with an indigenous tribe in the Amazon forest. During his stay, he fathered a son with a native woman. Koiti visited him while he lived with the tribe and, bidding him farewell at visit's end, Kootaro told him in a secretive tone: "Don't forget the Amazon Rainforest. Protect the Amazon Rainforest because it's there where the future of Brazil lies. And that of Japan's!" (MIYAZAWA, 2006, p. 215). The scientific meaning of the message is clear to today's readers; Kootaro is also letting him know that, although assimilated, he feels equally for both countries, that he is truly Japanese Brazilian, a third space. At the time, Koiti was puzzled by these words but now, years later, he understands them, because in a subsection of this part, also entitled "The Journey," the narrative voice (Koiti?) concludes that there are two categories of Japanese in Brazil: "those who follow a general orientation dictated by humanity's development, and those who also follow a general orientation, but one dictated by a long-standing cultural heritage. They are different paths, like two parallel lines. They are headed in the same direction but have different fates" (MIYAZAWA, 2006, p.226). Koiti's journey ends with his running into Minako, his former wife, at a subway station. While they head to a nearby restaurant, a loose balloon on the street bounces off his leg. He picks it up and a little Japanese girl accompanied by her mother, both dressed in kimonos, approaches him to regain her lost toy. After he returns it, she kisses him on the cheek and thanks him in Japanese, "arigatou... jichan" ("Thanks, grandpa"). Minako, noticing that his eyes swelled with tears, asked him what happened. The little girl's appearance and gratitude brought upon him an overwhelming sense of nostalgia for Japan. He answered, “Didn't you hear?... She called me jichan" (MIYAZAWA, 2006, p. 253).

The second book to be analyzed is Yellow on the Outside, Shame on the Inside: Asian Culture Revealed by Anson Chi. This "didactic" novel, so labeled by the author, surprisingly delivers a colonist's discourse on Asianness.
Born in New York to migrants, Chi, in Orientalist fashion, schematically disparages the cultures of East Asian countries, which he lumps together into a generic "Asian culture." (It is revealing that the author goes to extremes to conceal the ethnicity of the protagonist who the reader is left to infer to be "Asian," and who refers to the U.S. majority group as "Americans," not Europeans.)

The 130-page novel relates the pampered and dissolute life of a firstgeneration, upper-middleclass Asian American, Johnson, who disparages Asian culture and blames it for his alienation and failures. Never does he show appreciation for his parents who, though immigrants with limited English-language skills, have provided exceedingly well for him and his sister, e.g., Johnson drives an expensive vehicle and frequents clubs where he treats others to twenty-dollar drinks, all on his father's account. Neither child works in or outside the home; both are only expected to do well in school and in the Medical College Admission Test (MCAT), a must if they are to become medical doctors. The novel concludes when he and his friend Gabriel, also an Asian American, having failed the MCAT, decide to take the implied "Asian way out:" suicide.

Interspersed throughout a narrative that may be described as sophomoric, Johnson explains his relatives' and friends' behavior through his "Asian Pride Theorems:" money, status, and power. To him, Asians are generally motivated by these objectives and act accordingly to attain them, even to the exclusion of love and affection. He is somewhat correct when he states that Asians migrate to America for economic reasons, not to seek "freedom" (MIYAZAWA, 2006, p. 14). I say "somewhat" because this motive is not limited to Asians, but includes almost all immigrants who, upon arriving in the US, are not classified as "refugees" or "exiles." He also fails to see that these theorems are applicable to most members of capitalist societies, and are not limited to ethnicity or race. 
His own identity, developed within the American society, is impacted by the althusserian concept of "interpellation," that is, by directing racist epithets at, or by making prejudiced observations about the subject ("Other"), the ideological state apparatus ("Orientalist") manifests the hegemony that is intended to express and confirm its superiority. The Other perceives and shapes his self through that interpellation. He may, on the one hand, become more aware and proud of his race and/or ethnicity while developing a mistrustful antipathy toward the Orientalist. On the other hand, he may become subconsciously self-loathing and desirous to please the Orientalist by not entirely accepting his own "otherness," and by believing that Orientalist stereotypes to be true, and by thinking that only through their abolishment will his group attain postmodernity and thus become "civilized." In Yellow in the Outside, a racist exchange occurs when Johnson greets a white gas station attendant who, initially refusing to return Johnson's salutation, complies while asking, “Isn't there some rice you should be picking?" (CHI, 2017, p. 30). Johnson retorts with a racist question of his own; unhesitant, he attributes the attendant's prejudice to his low socioeconomic status, not as a manifestation of the colonizer's ideology. $\mathrm{He}$ is de facto made to feel as the Other, a foreigner in his native land, a worldview-shaping experience. The gas station attendant understands that, as a hegemonic agent, he still upholds his superiority with this interpellating pseudo-apology: "See here, Chinaman. I'm just yanking yer chain" (CHI, 2017, p. 30).

Most if not all Asian stereotypes that Edward Said discloses in Orientalism are contained in this work. Let us examine this claim through Johnson's comments and observations. Several are his pertinent stereotypical remarks, but I limit myself to one sample per category:

¿ Orientals possess inherent racial traits (SAID, 1979, p.38-39). The yellow race shares general characteristics, "With just my three simple
Asian Pride Theorems, I can reveal the truths about Asian culture whether it's Japanese, Korean, Chinese, Vietnamese, Thai, etc.-and all the reasons why Asians do the things that they do. First, Asians are obsessed with money and will do anything to get it. Second, money is conducive to the status that Asians seek, hence 'doctor or lawyer'. Third and uppermost, Asians want power: the power to control, the power to influence, the power to persuade, the power from attention, the power over relationships-these 'personal powers' do not seem like a big deal (since they're not exactly big powers like governmental or corporate power) but trust me when I say that they're everything to Asians. I know that it's hard to believe what I'm saying, that smart, straight-A, hardworking Asians can be so devious and diabolical" (CHI, 2017, p. 14).

$\bigotimes$ The Orient is strange (SAID, 1979, p.71-72). Asians display unusual behavior and customs, “I told Gabriel [Johnson's best friend] about my separate bed, separate room theorem a while back and he agreed indubitably. In fact, he reciprocated with a story about the strict, bizarre Asian behavior of child swapping. If a child of one Asian family performs poorly in school, then that family will swap its child with another child, typically from a relative. This can be thought of as a military school program, to strengthen and discipline both children into exceedingly exceptional students. With all this swapping, Asian parents should become swingers themselves-stupid joke, I know. Because of these types of strict, bizarre behaviors, it's no wonder that there's a lack of affection in Asian families. Most people don't know this, but it's very uncommon for Asian parents to hug their kids; and it's extremely rare for Asian parents to kiss their kids" (CHI, 2017, p. 17-18).

¿ The Orient is timeless (SAID, 1979, p.96). Asian ineptness is attributable to the continent's changelessness, "Throughout the 
thousands of years of Asian dynasties, all the emperors, kings and presidents have ruled with an iron fist and formidable will, controlling every aspect of the lives of Asians. Because of the long duration and large-scale domination, it's only natural that Asians continue living lives of subservience and docility, indoctrinated and conditioned beyond belief. Asians, thus, can't stand up for themselves, instead, let themselves get pushed around by those "above." They only know how to serve and to follow orders, thus, stifling their creativity and mental capabilities, resulting in the lack of intuition and preventing the utilization of common sense" (CHI, 2017, p.129).

¿ The Orient is degenerate (SAID, 1979, p.206). Asians lack morals and must be civilized, "The Chinese work like slaves, too, but are known to be cheap and will do anything-like putting melamine in milk or lead in toys-just to save money, throwing morals and ethics out the window. Then you have the rest of Indochina-the Vietnamese, Laotians, Cambodians, too many to list-following the Chinese, Korean, and Japanese, striving to obtain a small piece of that greed-filled pie. It's true that ethnic heritages like Japanese, Korean, Chinese, and Vietnamese are different, but they are all the same when it comes to one thing: money. They all want there (sic) kids to grow up to become doctors and lawyers; why? - money. They all want to live in the United States of America; why? - money. Remember, they can care less about freedom, liberty, and patriotism-that's insignificant compared to money (CHI, 2017, p. 87).

¿. The Orient is feminine (SAID, 1979, p. 207). Asian men are less manly; women are sexually promiscuous, "Too bad Asian guys have small you-know-what, down you-know-where, so prostitution is out of the question" (CHI, 2017, p.10); "Club Mode provides a bountiful harvest of scantily clad Asian girls, wearing the sexiest and skimpiest outfits: lacy halter tops, strapless corset dresses, skinny satin pants, seductive swing skirts, and the most erotic of all, come-fuck-me shoes-stunning spike heel platforms, peeping-tom pleaser pumps, thigh-high leather boots, strappy stiletto sandals-oh please have mercy on me!" (CHI, 2017, p.121).

As seen, Miyazawa's and Chi's works reflect differing East Asian perspectives and adaptation modes in the Americas. While Race plays a role in their third space formulation, culture predominates. But, while Miyazawa appropriates Japanese culture in his novel's denouement, Chi rejects what he considers to be Asian values throughout his, relying on stereotypes. Both works, however dissimilar, nonetheless share a constant: they reveal the prevailing ambivalence contained within hybridity.

\section{References}

BODNAR, John. The Transplanted: A History of Immigrants in Urban America. Indiana: Indiana University Press, 1985.

CHI, Anson. Yellow on the Outside, Shame on the Inside: Asian Culture Revealed. Disponível em: <https://www.free-ebooks.net/ebook/Yellow-on-the-outside-Shameon-the-Inside-Asian-Culture-Revealed>. Acesso em: May 2, 2017.

HIRABAYASHI, Lane Ryo; KIKUMURA-YANO, Akemi. New Worlds, New Lives: Globalization and People of Japanese Descent in the Americas and from Latin America in Japan. Palo Alto: Stanford UP, 2002

LESSER, Jeffrey. A Discontented Diaspora: Japanese Brazilians and the Meanings of Ethnic Militancy 1960-1980. Durham and London: Duke U, 2007.

MASTERSON, Daniel M.; SAYAKA, Funada-Classen. The Japanese in Latin America. Urbana and Chicago: University of Illinois Press, 2004

MIYAZAWA, Júlio. Yawara! A Travessia Nihondin-Brasil. São Paulo: Author's Edition, 2006 
SAID, Edward W. Orientalism. New York: Vintage Books, 1979.

SUZUKI JR., Matinas. História da discriminação contra os japoneses sai do limbo. Folha de São Paulo. 20 April 2008.

UBA, Laura. Asian Americans: Personality Patterns, Identity, and Mental Health. New York: The Guilford Press, 2003.

Recebido em 12/02/2018.

Aceito em 20/04/2018. 